\title{
IDENTIFICATION: THE EFFECT OF MATHEMATICAL COMPETENCE ON PEDAGOGIC COMPETENCY OF PROSPECTIVE TEACHER
}

\author{
Asrial $^{1}$, Syahrial ${ }^{2}$, Dwi Agus Kurniawan ${ }^{3}$, Faizal Chan ${ }^{4}$, Putut Nugroho $^{5}$, Reza Aditya Pratama ${ }^{6}$, Retno \\ Septiasari $^{7}$ \\ 1, 2, 4, 5, 6,7 Universitas Jambi, Elementary Teacher and Education, Indonesia, ${ }^{3}$ Universitas Jambi, Physics Education, \\ Indonesia \\ E-mail: asrial@unja.ac.id, *asrial@unja.ac.id, asrial@unja.ac.id, asrial@unja.ac.id, asrial@unja.ac.id, asrial@unja.ac.id
}

Article History: Received on $02^{\text {nd }}$ May2019, Revised on $30^{\text {th }}$ June 2019, Published on $22^{\text {nd }}$ July 2019

\begin{abstract}
Purpose of Study: The aim of this study was to determine the mathematics competencies and pedagogical competencies of prospective teachers and to determine the effect of mathematical competencies on pedagogical prospective teacher competencies in Elementary School Teacher Education.
\end{abstract}

Methodology: Quantitative research on this type of survey uses a sample of 540 prospective teachers.

Findings and Results: The results of this study were that prospective teachers mathematics competencies tended to be predominantly or less dominant with a percentage of men of $34.5 \%$ and $34.4 \%$ of women and pre-service pedagogic competencies in primary school education study programs classified as tend to be more or less dominant with the percentage of men $36.8 \%$ and women $33.3 \%$, and there is an influence between mathematical competencies on pedagogic competence of prospective teachers in Primary School Teacher Education at Jambi University.

Implication/Application : Research conducted by researchers is useful to provide input and motivation to prospective elementary school teachers regarding the improvement of the competence of an elementary school teacher candidate teacher to implement his pedagogic science in elementary school.

Keywords: mathematical competence, pedagogic competence, the influence of competence (First letter must be capital)

\section{INTRODUCTION}

Prospective teachers as prospective teachers are required to have good pedagogical competence. Pedagogical competence with regard to the principles of learning. Hakim (2015) Pedagogical competencies are competencies relating to the ability of a teacher including understanding the characteristics of prospective teachers, mastering the learning process and selfactualization. One important competency is competence in the field of mathematics. The success of mathematics learning is closely related to mathematical competencies and pedagogical competencies possessed by prospective teachers. The level of pedagogical competence of prospective teachers will affect the level of mastery of prospective teacher material. Asante et al. (2012) One of the factors that affect prospective teacher performance is the math teacher and their math lesson at school. Prospective teachers must add a variety of knowledge about mathematics in preparation for the task to be performed. Teacher competency is part of the requirements to achieve a synergistic effect on prospective teacher s arranged in three groups: teacher competence to promote cognitive processes (for example, knowledge in broad terms and (meta) cognitive strategies), teacher competencies to promote motivational-effective processes, and teacher competence to promote social processes in prospective teachers Peklaj (2015).

The success of learning mathematics is influenced by the skills of prospective teachers, namely their teaching skills. Tiurma et al. (2017) Teachers as determinants of educational success are required to have pedagogical competence. Professional teachers should ideally master a variety of learning models and can to apply them in accordance with prospective teacher conditions and learning objectives. Especially prospective teachers in elementary schools who must have high-level pedagogical competence in mathematics to create meaningful learning. Tiurma et al. (2017) UNESCO; (1) learning to know,learning to do, (3) learning to be (learning to be yourself), (4) learning to live together (learning to live togethersocial). Minarni et al. (2016) Teachers should know and implement learning approach efficient to support and facilitate prospective teachers mathematical comprehension and mathematical representation. When the lecture takes place, the prospective teacher is educated by the lecturer in order to improve the competency of the teacher candidates.

Improving math competencies for prospective teachers is obtained through Basic Mathematics lectures in college. Basic 
Mathematics Lectures are taught so prospective teachers know the basic theories taught when they are in high school. The purpose of studying Basic Mathematics is to improve prospective teachers' understanding of matter with abstract objects such as multiplication, addition, division, and reduction and problem solving through understanding material. Immaculate et al. (2011) Components of innovative forms of use of various tools, promotion of punishment and communication between prospective teachers are well-designed and well dedicated at the same time and also pedagogical practices. In addition to understanding the material, what is done by prospective teachers is to plan, implement and evaluate innovative learning through learning Basic Mathematics. Rahayu (2017) Canto plan, to implement, to evaluate innovatively through applying mathematics dictate pedagogics concepts and mathematics knowledge and also to make use various learning sources, technology, and science which are life skill oriented. The teacher is not equipped with sufficient knowledge about media and learning resources for mathematics. But prospective teachers must also equip themselves with the skills to choose and use media and learning resources well as innovations in learning.

The biggest challenge for mathematics teachers is to instill mathematical rules and concepts in an effective way so learning becomes meaningful. Fouze and Amit (2017) giving prospective teachers mathematical rules and content in a more effective, fun, and successful way is one of the challenges for the teacher. Prospective teachers who have understood the basic mathematics material properly and correctly in choosing media and learning resources for mathematics will not experience difficulties in delivering mathematics material in class. Mehmet et al. (2013) Teachers who have high achievements in mathematics are more competent in taking has a role in the achievement in the mastery of mathematical material, prospective teachers in math and science as perceived by teachers. The implementation of the knowledge of prospective teachers towards mathematics learning can be in the form of experience managing the class so that the things that have been conveyed are truly understood by prospective teachers. Teachers in a learning process, are required to be able to create an effective learning environment and be able to manage the class so that prospective teachers get optimal learning outcomes. So, the learning process is really well implemented.

This study aims to determine the competency of mathematical knowledge possessed by the prospective teachers in the Primary School Teacher Education program. The questions in this study are:

1. What is the pedagogical competencies possessed by the prospective teachers of the Primary School Teacher Education program?

2. What is the competency of mathematics knowledgepossessed by the prospective teachers of the Primary School Teacher Education program?

3. How does the influence of mathematical knowledge competency on pedagogic competence of pedagogic prospective teachers elementary school teacher education programs?

\section{LITERATURE REVIEW}

Pedagogic competence is an ability related to students' understanding and manager of learning that is educational and dialogical. From his point of view, the teacher should not only reflect in general but also must use certain concepts and ideas to be reflected, such as teaching methods, teaching materials, communication with students, cooperation with coworkers. Maksimovic and Osmanovic (2018). In substance, this competency includes the ability to understand students, design and implement learning, evaluate learning outcomes, and develop students to actualize their various potentials. According to Akmal (2017) "Pedagogical Knowledge (PK): PK relates to teaching methodologies and approaches, including knowledge in teaching and classroom management, assessment, evaluation, development of lesson plans (RPP), and student learning". Pedagogic itself can be interpreted as the science of education which emphasizes more on thinking and reflection on education, pedagogic a theory that is carefully critical, and objectively develops its concepts regarding the nature of humans, the nature of children and the nature of the purpose of education. Ilghiz and Signagatullin (2019) argues that competent teachers are teachers who are able to manage learning programs. Therefore, pedagogic competence is very necessary.

Improving math competencies for prospective teachers is obtained through Basic Mathematics lectures in college. Basic Mathematics Lectures are taught so prospective teachers know the basic theories taught when they are in high school. The purpose of studying Basic Mathematics is to improve prospective teachers' understanding of matter with abstract objects such as multiplication, addition, division, and reduction and problem solving through understanding material. Immaculate et al. (2011) Components of innovative forms of use of various tools, promotion of punishment and communication between 
prospective teachers are well-designed and well dedicated at the same time and also pedagogical practices. In addition to understanding the material, what is done by prospective teachers is to plan, implement and evaluate innovative learning through learning Basic Mathematics. Rahayu (2017) Canto plan, to implement, to evaluate innovatively through applying mathematics dictate pedagogics concepts and mathematics knowledge and also to make use various learning sources, technology, and science which are life skill oriented.

Mathematics is one of the learning in elementary schools that requires strengthening of everyday life. Basically mathematics is a lesson that contains abstract formulas and concepts that make it difficult for students to just imagine and not be given real examples by the teacher in the lives of students. As stated by Fouze and Amit (2017). That "Mathematics has characteristics as an abstract object, which causes most students to experience difficulties and a mathematics teacher experiences difficulties in menstruating concepts". Integration of local wisdom and culture is needed to facilitate teachers in delivering mathematics learning.

\section{METHODOLOGY}

\section{Research design}

This study uses a quantitative research approach with a type of survey. Survey research is a procedure in quantitative research where researchers administer surveys to a sample or to the entire population used to describe population attitudes, opinions, behaviors, or special characteristics Creswell and . (2012). Data analysis using inferential statistics. The analysis uses mean, median, percentage, and regression analysis. Regression analysis, which is used to describe the model of influence between two variables, namely mathematical competence (x) and prospective teacher pedagogical competence (y).

\section{Research subject}

The population in this study were all elementary school teacher education prospective teachers totaling 770 prospective teachers. The total number of prospective teachers in the sample was 540 prospective teachers in Elementary School Teacher Education, Jambi University. Male prospective teachers numbered $87(16.1 \%)$ and female prospective teachers numbered $453(83.9 \%)$ all of whom were aged 18-22 years. Sampling is done by purposive sampling technique. Purposive sampling is a sampling technique based on the criteria of the researcher Kerlinger (2014).

\section{Instrument}

The instruments used were multiple choice questions and interview sheets and questionnaires. Multiple choice questions with 4 answer options with one correct answer. And the number of questions is 30 items. The interview sheet used was structured interviews conducted on the pre-service studio teacher program of Primary School Teacher Education who had completed lectures on Basic Mathematics Concepts, Mathematics Education in elementary schools and mathematical models. Sharon and Halcomb (2009) Interviews are most commonly associated with qualitative research. However, they can be a useful tool in mixed methods research, either by providing qualitative data to be integrated with a quantitative dataset or by collecting mixed data. While in the questionnaire instrument there were four answer options, namely very good, good, not good and very not good. The questionnaire is a technique of collecting data where participants or respondents fill in a question or statement later after being filled in with a complete return to the researcher Creswell and . (2012).

Multiple choice questions are used to obtain data on mathematical competencies possessed by the prospective teachers at the Jambi elementary school teacher education study program. The following below is a category of multiple choice questions with four options, which are very good, good, not good and not good.

Table 1: Categorization of multiple choice questions for mathematical pedagogic competence

\begin{tabular}{ll}
\hline Category & Value Ranges \\
\hline Very Good & $76-100$ \\
\hline Good & $51-75$ \\
\hline Not Good & $26-50$ \\
\hline Very Not Good & $0-25$ \\
\hline
\end{tabular}

The use of questionnaires aims to obtain data on pedagogic competencies possessed by the prospective teachers in the education study program of Jambi elementary school teachers. The following are the questionnaire tables with four categories, 
which are very good, good, not good and not good.

Table 2: Categorization of the value of the Pedagogic competency questionnaire

\begin{tabular}{ll}
\hline Category & ValueRanges \\
\hline Very Good & $47-57$ \\
\hline Good & $36-46$ \\
\hline Not Good & $25-35$ \\
\hline Very Not Good & $14-24$ \\
\hline
\end{tabular}

\section{RESULTS}

Teacher's pedagogic competence is seen from the mastery of the content of a material, mastery of innovation in learning media, mastery in terms of teaching techniques (models, methods, and strategies). The renewability in this study is more specific about the pedagogic competence of a primary school teacher candidate who must also be reviewed by mathematical competency abilities. It is important that prospective elementary school teachers must understand the study of mathematical material, innovation and learning strategies that must be used in teaching mathematics.

Mastery of competence is very important for a teacher. Competence plays an important role for teachers in implementing learning well. Kaendler, et al (2015) define competencies as the ability to perform tasks in a specific situation, for instance, a classroom situation, in a flexible and adaptive fashion. Currently the factor of pedagogic competence, prospective teacher professionals are highly preferred for Jambi university prospective teacher s, because according to the law a teacher must master 4 competencies. According to Law No. 14 of 2005 concerning Teachers and Lecturers Article 10, namely 1,) Teacher competencies as referred to in Article 8 include pedagogical competencies, personality competencies, social competencies, and professional competencies obtained through professional education. The renewal in this research is to strengthen the system of increasing competence at the prospective teachers.

Table 3: Multiple-choiceProspective teachers Mathematics Competence Results

\begin{tabular}{|c|c|c|c|c|c|c|c|}
\hline & \multicolumn{3}{|l|}{ Male } & & \multicolumn{3}{|l|}{ Female } \\
\hline & Category & Frequency & $\%$ & & Category & frequency & $\%$ \\
\hline \multirow{4}{*}{$\begin{array}{l}\text { Prospective } \\
\text { teachers } \\
\text { elementary } \\
\text { education }\end{array}$} & Very good & 9 & 10,3 & \multirow{4}{*}{$\begin{array}{l}\text { Prospective } \\
\text { teachers } \\
\text { elementary } \\
\text { education }\end{array}$} & Very Good & 57 & 12,6 \\
\hline & Good & 21 & 24,1 & & Good & 113 & 25 \\
\hline & Not good & 30 & 34,5 & & Not Good & 156 & 34,4 \\
\hline & $\begin{array}{l}\text { Very not } \\
\text { good }\end{array}$ & 27 & 31,1 & & $\begin{array}{l}\text { Very Not } \\
\text { Good }\end{array}$ & 127 & 28 \\
\hline Total & & 87 & 100 & Total & & 453 & 100 \\
\hline Total & & 540 & & & & & \\
\hline
\end{tabular}

\section{Descriptive Results of Pedagogic Competence}

The following are the results of multiple choice data to obtain data on the mathematics competencies of the prospective teacher's education program in Jambi elementary school teachers.

Based on table 3 above, out of 540 respondents divided into 87 males and 453 females producing male data included in the very good category with a percentage of $10.3 \%$, good category with a percentage of $24.1 \%$, not good category with percentage of $34.5 \%$ and $31.1 \%$ included in the very not good category. While 453 female respondents produced $12.6 \%$ of the data included in the very good category, $25 \%$ including the good category, $34.4 \%$ included in the not good category and $28 \%$ included in the very not good category. This data shows that most of the existing categories are not good.

\section{RESULTS OF MATHEMATICS PEDAGOGIC COMPETENCE}

The following are the results of the questionnaire to obtain data on pedagogic competencies. Prospective teachers education study program for Jambi elementary school teachers.

Based on table 4 , there were $16.1 \%$ in the male respondents included in the very good category, $19.5 \%$ in the good category, 
Table 4: Results of the questionnaire pedagogic competencies

\begin{tabular}{|c|c|c|c|c|c|c|c|}
\hline & \multicolumn{3}{|l|}{ Male } & & \multicolumn{3}{|l|}{ Female } \\
\hline & Category & Frequency & $\%$ & & Category & frequency & $\%$ \\
\hline \multirow{4}{*}{$\begin{array}{l}\text { Prospective } \\
\text { teachers } \\
\text { elementary } \\
\text { education }\end{array}$} & $\begin{array}{l}\text { Very } \\
\text { good }\end{array}$ & 14 & 16,1 & \multirow{4}{*}{$\begin{array}{l}\text { Prospective } \\
\text { teachers } \\
\text { elementary } \\
\text { education }\end{array}$} & Very good & 61 & 13,5 \\
\hline & Good & 17 & 19,5 & & Good & 122 & 27 \\
\hline & $\begin{array}{l}\text { Not } \\
\text { good }\end{array}$ & 32 & 36,8 & & Not good & 151 & 33,3 \\
\hline & $\begin{array}{l}\text { Very not } \\
\text { good }\end{array}$ & 24 & 27,6 & & $\begin{array}{l}\text { Very not } \\
\text { good }\end{array}$ & 119 & 26,2 \\
\hline Total & & 87 & 100 & Total & & 453 & 100 \\
\hline Total & & 540 & & & & & \\
\hline
\end{tabular}

$36.8 \%$ in the not good category and $27.6 \%$ in the category very not good. While female respondents indicated that there were $13.5 \%$ including in the very category, $27 \%$ including the good $\mathrm{c}$ ategory, $33.3 \%$ including the not good category and $26.2 \%$ including the very not good category. Based on these data, male and female respondents have a tendency or more dominant to be included in the poor category.

While the following results of interviews conducted with respondents regarding grading of mathematical competencies and pedagogical competencies prospective teachers education study program for Jambi elementary school teachers.

1. I improve my mathematical competence through lectures on the basic concepts of mathematics.

2. Tics and mathematics education in elementary school. However, I don't like learning which leads to mathematical aspects.

3. Pedagogic competence is a very important competency for a teacher. By mastering pedagogical competencies, I can master learning material, classroom management, evaluation of learning and understanding prospective teachers. So I have to improve my pedagogical competence, one of which is through mathematical competence.

4. Pedagogic competence is very important for a teacher. So I have to improve these competencies.

5. By mastering good pedagogical competencies I can understand the characteristics of prospective teachers, conduct good classroom management, carry out effective learning and evaluate learning. These things can also be implemented in subjects in mathematical aspects.

6. I do not like courses in the field of mathematics, because mathematics is very boring.

7. Mathematics lectures on campuses are less interesting because the methods in lectures are too monotonous such as discussion and presentation.

8. I really like the basic concepts of mathematics courses and mathematical learning models. Because mastery of mathematical competencies can facilitate me when I become a teacher later.

9. The course in mathematics is one of my favorites. I will improve my mathematical competencies by taking good lectures.

\section{Hypothesis Test Analysis}

The following are the results of the regression of mathematical competencies on pedagogical competencies of prospective teachers of education programs in Jambi elementary school teachers.

Based on the test shows that mathematical competence has an influence on pedagogical competencies. Having good mathematical competencies for prospective teachers will support pedagogical competence. Mathematical competence is part 
Table 5: Results of Regression

\begin{tabular}{llllllll}
\hline & \multirow{2}{*}{ Variable } & \multicolumn{5}{c}{ pedagogical competencies } \\
\cline { 3 - 7 } & & $\min$ & $\max$ & $\mathrm{X}$ & $\mathrm{P}$ & $\mathrm{R}$ & $\mathrm{R}^{2}$ \\
$\begin{array}{l}\text { Prospective } \\
\text { teachers }\end{array}$ & mathematical & 14 & 52 & 38,28 & 0,02 & 0.85 & 0.72 \\
$\begin{array}{l}\text { elemen- } \\
\text { tary }\end{array}$ & competence & & & & & & \\
education & & & & & & & \\
\hline
\end{tabular}

of pedagogic competence. Mastery of mathematical competencies will affect the level of prospective teachers pedagogic competence. Teacher's pedagogic competency concerns the principles of learning. Akmal (2017) Pedagogical Knowledge (PK): PK relates to teaching methodologies and approaches, including knowledge in teaching and classroom management, assessment, evaluation, development of lesson plans (RPP), and prospective teacher learning. Having good mathematical competencies will make it easier for teachers to carry out learning in accordance with the demands of pedagogical competence.

\section{DISCUSSION}

Mathematical competence underlies the mastery and understanding of mathematics. Efforts to improve the mathematics competencies of prospective teachers study programs in Jambi university elementary school teachers through courses in basic concepts of mathematics, elementary school mathematics, and mathematical models. Through courses in the mathematical aspects of prospective teacher s can improve mathematical competencies that will be useful when they become teachers later. While pedagogic competence is a competency that leads to mastery of the material. Obot (2013) Pedagogical knowledge is not exactly the same thing as knowledge of the subject matter. However, they are nevertheless intimately linked. This is because mastery and use of pedagogical knowledge in the implementation of learning in the classroom will show how much competence they have about the subject matter. This shows that mastery of mathematical competencies contributes to pedagogical competence. Mathematical competencies of prospective teacher prospective teachers have an influence on pedagogical competencies. Having good mathematical competence means that pedagogical competence is also good Kumalasari, Setiawan, \& SummerSlam (2017) .Teacher's pedagogic competence is the teacher's ability to manage lessons that complement the understanding and knowledge base of education that has academic and intellectual expertise. Mastering good pedagogical competencies show the level of professionalism of the prospective teachers. Beijaard, Meijer \&Verloop Dalam Koutouzis dan Spiriadou (2017) said that Teachers Professional Identity: 1) is (re)structured during the continuous and uninterrupted process of interpretation of, feedback from and self-reflection on teachers experiences, 2) is the result of the interaction between their individual characteristics and the social context, and consequently there is no single and unique Professional Identity, 3) consists of individual Sub-Identities, some of which are in harmony with each other, while others in conflict. Moreover, professional development is a key component, as teachers are in a constant process of development.

$\mathrm{T}$ he other hand, lectures on subjects in the mathematical aspects must be carried out creatively and innovatively. Sidabutar (2016) Innovative learning in approaching strategies, methods, and functions used in mathematics learning at a certain level of education. Lectures must be carried out in various interesting ways and sources of learning. Unfortunately, the learning resources used are only from books so that the mastery of the material is not deep. Marmah and . (2014) In the teaching method of a lecturer is the main focus of information transfer. The use of lecturers' methods and strategies in delivering lecture material can attract the attention of prospective teachers in learning. Thus the prospective teacher's math competency in increasing. The lack of interest of prospective teachers towards lectures in subjects in the mathematics aspects will result in a lack of understanding and mathematical competencies. The lack of motivation of the prospective teachers has an impact on the lack of enthusiasm for the prospective teachers in lectures such as being lazy to do geometry assignments. Koparan et al. (2015) Aesthetic development and inductive skills prospective teacher s can be obtained through geometry learning. This shows the influence of the mastery of mathematical competence on the pedagogical competence of the prospective teachers.

On the other hand, the lecturer aims to make prospective teachers construct their own knowledge. One of the effects of Constructivism is that prospective teachers can build their own knowledge by experiencing and doing it, in the process of 
entering the real world continuously, so that facts and skills are learned holistically and there is a process of connecting new knowledge and skills into the knowledge and skills that have been possessed previous (Wilson \& Osman, 1995 ; Karlinaet al, 2019 ). But because prospective teachers' interests and motivations are low so the goals are not implemented. In addition to the above constraints, prospective teachers also experience other obstacles, such as during learning the lecturer has taught prospective teachers the types of methods and techniques used in delivering learning. However, prospective teachers have not learned in detail how to use methods and techniques that are in accordance with the mathematics learning material and the real conditions of prospective teachers. This is also due to prospective teachers rarely doing primary school prospective teacher learning simulation directly. Koparan et al. (2015) The disharmony between intuition and reality in mathematics education arises because of limited experience. Prospective teachers only carry out simulations in class, which of course the conditions are much different because those who become prospective teachers are not elementary school age children but other prospective teachers. This condition is an obstacle for prospective teachers to get pedagogical competence.

Prospective teacher must understand the concept of learning in elementary school obtained from the lecture period. Prospective teachers must obtain sufficient practice and simulation. Because elementary school is the first step for prospective teachers to build their knowledge. Primary school is the first step at which a child meet schools experience. Elementary school acts as the basis for learners to acquire future knowledge to learn later and give children the necessary learning habits, children need to spend this period in the environment and in good conditions Girmen et al.(2018).

\section{CONCLUSION AND SUGGESTION}

Based on the explanation of the results and the discussion, the mathematical competence conditions of prospective teacher $\mathrm{s}$ belong to the category tend to be less good while the prospective teacher's pedagogic competencies are categorized as less good. While the regression results show that mathematical competencies are very influential in improving prospective teachers' pedagogical competencies. The importance of mathematical competencies for prospective teachers must be used as a benchmark for obtaining high pedagogical competencies for prospective teachers.

Suggestions from researchers are so that the teacher tries to make good planning in the RPP before applying pedagogical competencies in the classroom, and the teacher provides the best solutions from those who want to be adapted in implementing pedagogical competencies in Elementary School.

\section{REFERENCES}

Akmal, A. (2017). LocalCulture and Morality Attachment to TpachFrameworkOf Pre-ServiceEnglishTeachersWithinThe ChallengeOf The 21st CenturySkills. International Journal of Education, 9(2):113-113.

Asante, J., \&amp; D K Nsiah, and ., M. (2012). The Effect of Ghanaian Prospective teachers Content Knowledge on Their Mathematical Knowledge for Teaching Basic School Mathematics. African Journal of Education Studies in Mathematics and Sciences, 10:23-37.

Creswell, J. and ., W. (2012). America: Library of Congress Cataloging in Publication Data. Educational Research Methodology, pages 1-298.

Fouze, A. and Amit, M. (2017). On the Importance of an Ethnomathematical Curriculum in Mathematics Education. Science and Technology Education, 14(2):561-567. Eurasia Journal of Mathematics.

Girmen, P., Kaya, M. F., and Kilic, Z. (2018). Violence at primary schools and its reflections on the press and the visual media in Turkey. International Journal of Research in Education and Science (IJRES), 4(2).

Hakim, A. (2015). Contibution of Competence Teachers On the Performance of Learning. The International Journal of Engineering And Science, 4(2):1-12.

Ilghiz, M. and Signagatullin (2019). Developing Preservice Elementary Teachers Global Competence. International Journal of Educational, 28(1):48-62.

Immaculate, K., Elena, N., and Polotskaia (2011). Teaching through Mathematics Problems: Redesigned for a. Focus on Mathematics. International Journal of MathematicsTrends and Technology, pages 50-56.

Kerlinger, F. N. (2014). Foundations of behavioral research. Gadjah Mada University Press, Yogyakarta.

Koparan, T., Gul, D., and Kaleli, Y. (2015). The effect of Simulation-based Learning on Prospective Teachers Inference Skills in Teaching Probability. Universal Journal ofEducation Research, 3(11):775-786. 
Maksimovic, J. and Osmanovic, S. J. L. (2018). Teachers as reflective practitioners with the function of improving educational practice in primary schools in Serbia.Sodobna pedagogika. Journal of Contemporary Educational Studies, 69(4):306-324.

Marmah, A. and ., A. (2014). Prospective teachers Perception About The Lecture As A Method Of Teaching In Tertiary Institutions. Views of Prospective teachers From College Of Technology Eduction, Kumasi (COLTEK). International Journal of Education and Research, 2(6):601-612.

Mehmet, G., Ekber, T., and \&amp;fikret, K. (2013). -. Mathematics Special Content Competencies odElemtary School Teachers. Scientific Research, 4(12):1-10.

Minarni, A., Elvis, E., Rahmad, N., and ., H. (2016). Mathematical Understanding and Representation Ability of Public Junior High School in North Sumatra. Journal on Mathematics Education, 7(1):43-56.

Obot, I. M. (2013). Influence of teachers competence in subject matter on prospective teachers interest in the learning of social studies education in Akwa Ibom State. Nigeria. International Journal of Teaching and Education, 2(3):137-137.

Peklaj, C. (2015). Teacher Competencies through the Prism of Educational Research. Center for Educational Policy Studies Journal, 5(3):183-204.

Rahayu, D. V. (2017). Analysis of Prospective Mathematics Teachers Basic Teaching Skills. Journal of Physics: Conference Series, 812(1):1-5.

Sharon, A. and Halcomb, E. J. (2009).

Sidabutar, R. (2016). The Effort to improve Mathematics Learning Achievment Result of High School Prospective teachers as Required by Cempetency-Based Curriculum and Lesson Level-Based Curriculum. Journal of Education and Practice, 7(15):10-15.

Tiurma, S., Saut, P., \&amp;aman, and Simare-Mare (2017). The Improvement of Teacher Classy Ability Imlements the Paikem Learning Models Throught the Aplication of Clinical Suervision in SD RK Setia Budi Medan. IOSR Journal of Research \& Method inEducation, 7(5):8-11. 